Shapin, Steven, The Scientific Life: A Moral History of a Late Modern Vocation

\title{
Hugo Pinto
}

\section{OpenEdition}

\section{Journals}

Edição electrónica

URL: http://journals.openedition.org/rccs/521

DOI: $10.4000 /$ rccs.521

ISSN: 2182-7435

Editora

Centro de Estudos Sociais da Universidade de Coimbra

\section{Edição impressa}

Data de publição: 1 junho 2009

Paginação: 176-182

ISSN: 0254-1106

\section{Refêrencia eletrónica}

Hugo Pinto, "Shapin, Steven, The Scientific Life: A Moral History of a Late Modern Vocation », Revista Crítica de Ciências Sociais [Online], 85 | 2009, posto online no dia 01 outubro 2012, consultado o 21 setembro 2020. URL : http://journals.openedition.org/rccs/521 ; DOI : https://doi.org/10.4000/rccs 521 


\section{Recensões}

\section{Barthe, Yannick (2006), Le pouvoir d'indécision. La mise en politique des déchets nucléaires. Paris: Éditions Economica, 239 pp.}

Yannick Barthe introduz-nos de imediato no centro da problemática do livro ao abrir com a afirmação de que os resíduos nucleares são, para além de tudo quanto representam, um problema político - qualificação que deriva do facto de serem objecto de um tratamento particular por parte das autoridades públicas. A interrogação de partida que o autor coloca é, pois, a de saber de que forma um "facto" puramente técnico e científico, a gestão dos resíduos nucleares, adquiriu o estatuto de um problema societal que exige uma solução de ordem política. Ao impor-se como objecto de uma acção política, esta questão revela de modo eloquente que, ao contrário do esperado, os progressos científicos e tecnológicos não ditaram a morte do político, tendo antes contribuído para a sua extensão.

O campo do nuclear é um campo particular. Em primeiro lugar, porque, para muitos, é a ilustração quase perfeita de um tipo de relação entre saber técnico e poder político própria do modelo tecnocrático, de que fala J. Habermas, no qual os constrangimentos objectivos avançados pelos especialistas se impõem em detrimento do poder de decisão dos responsáveis políticos. Os resíduos nucleares são, para retomar a expressão de V. Gunter e S. Kroll-Smith, factos "em bruto" que exigem uma solução de ordem técnica. No final dos anos 80, essa solução estabiliza-se, ficando o leque de soluções limitado a uma irreversibilidade técnica: o armazenamento geológico. Em segundo lugar, porque é um campo que não se situa no mesmo plano dos novos riscos e das controvérsias tecnológicas. A questão dos resíduos nucleares acompanhou a indústria atómica desde os seus primeiros passos; no entanto, os debates e as controvérsias - que, em França, atingem o seu ponto mais alto no final dos anos 80 - aparecem no rescaldo da batalba, ou seja, depois de estarem já definidas as grandes orientações neste domínio. Os conflitos irão, por isso, cristalizar-se em torno de uma solução técnica, o armazenamento geológico, para a qual não parecem existir alternativas. É nesta medida que, para Y. Barthe, a noção que melhor caracterizaria as controvérsias que ocorrem num terreno já balizado, no qual abundam as irreversibilidades e são reduzidas ou nulas as soluções negociáveis, seria a de controvérsias pós-tecnológicas.

A questão de partida complexifica-se e ganha em abrangência: quando se questiona o modo como as irreversibilidades técnicas podem ser objecto de uma apreensão política o que se questiona é a capacidade dos poderes públicos para capturarem e reformularem, nos seus próprios termos, determinados desafios, para implementarem, orientarem ou reorientarem o curso de determinadas políticas, para agirem e introduzirem mudanças. Os conflitos suscitados pelos resíduos nucleares constituem, neste sentido, verdadeiros desafios para os dirigentes políticos, que se vêem na obrigação de tomar decisões, de agir e de introduzir mudanças que se encontram, à partida, comprometidas pela ausência de alternativas no plano técnico. Colocada desta forma, a história da politização dos resíduos nucleares parece desembocar num impasse. Desde logo, de que forma esta questão pode ser efectivamente 
capturada pelas instâncias políticas? Mesmo se capturada por estas instâncias, de que forma pode ser apresentada como exigindo decisões políticas quando a sua resolução assume os contornos de uma irreversibilidade técnica? Y. Barthe resolve este impasse pelo recurso a uma focalização da análise em dois processos - o processo de irreversibilização (irréversibilisation) e de reversibilização (réversibilisation) - empiricamente inteligíveis na questão da gestão dos resíduos nucleares a partir do desenrolar da sua trajectória histórica e dos actores que a acompanham. O processo de irreversibilização permite explicar o modo como uma solução técnica adquire, aos olhos de determinados actores, o carácter de irreversível. Subjacente a este processo encontra-se a hipótese de que, no caso dos resíduos nucleares, foi precisamente o processo de irreversibilização da solução técnica que abriu caminho para uma qualificação da questão como política, tornando possível a sua apreensão por instâncias políticas, ao invés de exclusivamente técnico-científicas. $\mathrm{O}$ segundo processo assenta, pois, no pressuposto de que os efeitos de transformação introduzidos pela politização dos resíduos nucleares pode desencadear um processo, inverso ao primeiro, de reversibilização de uma questão. O problema da gestão dos resíduos nucleares é abordado numa perspectiva histórica. Os dois processos descritos acima reenviam para duas temporalidades distintas da questão do tratamento dos resíduos nucleares em França, cada um deles desenhando os contornos de uma política particular. Até ao final dos anos 80 , o problema dos resíduos nucleares é marcado pelo processo de irreversibilização. O que não pode ser objecto de discussão escapa ao debate público e à deliberação política, que pressupõe a possibilidade de revisões e a existência de alternativas. Uma política que procura a irreversibilidade é, deste modo, uma política de despolitização (dépolitisation): tem por efeito excluir determinadas decisões do domínio do contingente para as inscrever no domínio da necessidade atemporal. Para que um projecto, como o armazenamento geológico dos resíduos nucleares, por exemplo, atinja a qualidade de irreversível, necessita de um trabalho contínuo de robustecimento da irreversibilidade, que, quando adquirida, o dota de uma força de inércia e torna resistente a qualquer investida ou desafios que se lhe possam vir a colocar.

Não podendo um projecto ser objecto de contestação e de revisão, é a própria contestação que deve ser objecto de revisão. Assim, no final dos anos 80, com a subida de escalada dos conflitos em torno da irreversibilidade do armazenamento geológico dos resíduos, o importante já não é proteger o ambiente dos resíduos nucleares através de uma solução técnica, mas proteger essa solução técnica do seu ambiente. Compreende-se, deste modo, o modo como a irreversibilidade pode constituir um recurso político poderoso: a irreversibilidade determina o quadro dos problemas a tratar e estabelece uma fronteira entre o que é e o que não é problemático, entre o que deve ser ou que não pode ser objecto de tratamento político.

Se o processo de irreversibilização procura pôr termo à carreira de um problema, o processo de reversibilização, pelo contrário, procura reavivá-lo. De que forma? Procurando retrospectivamente soluções que foram, então, afastadas, para alargar o leque dos possíveis e ampliar as margens de negociação. $\mathrm{O}$ processo de reversibilização é, em suma, um processo de interrupção da fatalidade que procura arrancar determinados projectos ou decisões à irreversibilidade. No caso dos resíduos nucleares, o que a dado momento foi considerado como apartado da questão - a aceitação social do armazenamento geológico - é 
reintroduzido no processo decisório, e o que era dado como não problemático - a solução técnica - torna-se novamente objecto de discussão. No contexto francês, a Lei 91-1381, de 30 de Dezembro de 1991, relativa às pesquisas sobre gestão dos resíduos radioactivos, ao resultar numa abertura do horizonte dos possíveis, irá ser fundamental, enquanto indecisão, para o processo de reversibilização da política de gestão dos resíduos nucleares. Mais adiante tornar-se-á mais claro em que consiste precisamente este poder de indecisão.

O processo de reversibilização procede, assim, por etapas. Pressupõe, num primeiro tempo, uma distinção entre responsáveis políticos e produtores de soluções técnicas, o que reduz o papel dos últimos ao de consultores (e não de decisores) e abre espaço para a afirmação da autonomia dos primeiros. E, num segundo, uma abertura da rede institucional que passa pela mobilização de novos actores que podem ir dos eleitos locais às associações, passando pelos próprios especialistas.

Para explicar os pontos que unem os processos de irreversibilização e de reversibilização, Y. Barthe insiste no argumento de que o primeiro pode, a dado momento, autosubverter-se e desencadear o segundo. Um e outro processo podem, deste modo, ser apreendidos como dinâmicas endógenas a um dado problema ou decisão. A força de um determinado projecto ou de uma decisão constitui a sua principal fraqueza, na medida em que é o próprio défice de flexibilidade que reduz as suas capacidades e possibilidades de adaptação aos desafios que se lhes colocam. Os conflitos emergentes, na medida em que não podem ser exteriorizados e tratados como problemas autónomos, podem produzir um efeito de retorno cujo resultado não se pautará apenas pelo questionamento do projecto ou da decisão em si, mas principalmente por um exame retrospectivo das condições que permitiram que se impusessem como irreversíveis. É esta leitura retrospectiva que pode desencadear o processo de reversibilização.

Finalmente, resta descrever em que consiste exactamente o poder de indecisão que dá título ao livro. Quando o trabalho político tem por principal objectivo reconstituir um espaço de escolhas onde só existiam irreversibilidades, pode assumir a forma de uma tomada de indecisão. A tomada de indecisão não equivale à ausência de decisão, que reenvia para uma atitude passiva, antes tem por efeito transformar a situação. No caso dos resíduos nucleares, a Lei 91-1381 traduziu-se na revogação das decisões assumidas anteriormente, entre as quais a irreversibilidade do armazenamento geológico, e no relançamento da investigação, abrindo, deste modo, o leque de possibilidades anteriormente dado como encerrado. A indecisão salvaguarda, pois, a possibilidade futura de decidir. $\mathrm{O}$ autor subverte um dos adquiridos comummente aceites em matéria de riscos colectivos, segundo o qual o grande problema derivaria da dificuldade em tomar decisões hard assentes em conhecimentos soft. O que o acompanhamento dos actores e da trajectória do problema dos resíduos nucleares revela é uma situação inversa, ou seja, que a dificuldade deriva em fazer prova de indecisão, introduzindo maleabilidade nas decisões que a história se encarregou de endurecer.

A indecisão necessita de um poder, o de tornar reversível o irreversível, mas é igualmente um modo de exercício do poder. Foi, de facto, precisamente a necessidade de tratar um problema considerado anteriormente como residual, a aceitação social do armazenamento geológico, que levou os decisores políticos a inscreverem-se numa lógica de reversibilização.

$\mathrm{O}$ que se pode esperar, pois, de uma postura de indecisão do ponto de vista da 
resolução de conflitos? É verdade que a indecisão, ao reportar no tempo uma decisão "definitiva”, é susceptível de constituir um recurso estratégico para que, paulatinamente, os poderes públicos consolidem uma irreversibilidade já decidida. No entanto, o processo decisório por indecisão introduz igualmente transformações que se traduzem na reavaliação da posição de determinados actores, na mobilização de associações ou grupos, na legitimação de determinadas reivindicações e na disseminação de novas opções de pesquisa. Por essa via, é a própria possibilidade de encerramento definitivo de um dado processo que se adia.

Em que é que isso constitui uma vantagem? $\mathrm{Y}$. Barthe finaliza com uma nota sobre as implicações do poder de indecisão. Segundo ele, estaremos talvez a assistir à emergência de um novo modo de governação dos desafios de carácter científico e tecnológico fundado na experimentação e em procedimentos abertos à reversibilidade e à autocorrecção. A generalização deste tipo de procedimento significaria que a gestão dos problemas e dos conflitos associados ao desenvolvimento científico e tecnológico passariam a ser marcados por soluções assentes em compromissos provisórios e, consequentemente, reversíveis. A ser este o caso, então sim, seria possível afirmar que as ciências e tecnologias fizeram finalmente a sua entrada na democracia.

\section{Pedro Araújo}

\section{Gatti, Gabriel (2008), El detenido-desaparecido. Narrativas posibles para una catástrofe de la identidad. Montevideo: Trilce, 176 pp.}

Em primeiro lugar convém advertir o leitor de que o livro de Gabriel Gatti, professor de teoria sociológica na Universidade do País Basco e coordenador do Centro de Estudos sobre a Identidade Colectiva, não aborda as temáticas da memória e da luta política pela justiça na Argentina e Uruguai, apesar destes aspectos se encontrarem presentes na obra. Neste sentido, o texto afasta-se dos temas e perspectivas dominantes em relação à questão do terror de Estado no Cone Sul latino-americano. O objecto de estudo deste livro é a identidade, um tipo de identidade individual e colectiva produto da modernidade. Mais concretamente, e olhando os efeitos do desaparecimento forçado de pessoas ao seu redor, Gatti analisa a catástrofe que o detido-desaparecido produz sobre essa identidade e as narrativas que a sustentam, procurando assim responder à seguinte pergunta: que narrativas possiveis surgem no espaço do detido-desaparecido? $\mathrm{O}$ au- tor considera que têm surgido duas narrativas que, em grande medida, coincidem com diferentes gerações e suas experiências nesse espaço: a narrativa que tenta reparar o sentido que foi destruído pela catástrofe, e aquela que abandona essa ideia e é construída partindo do sem sentido.

Este livro apresenta-se como atípico do ponto de vista narrativo e esta é uma das suas principais virtudes, porque consegue realçar o seu imenso potencial teórico e analítico. Por um lado, desconstrói a centralidade do autor e, por outro, interrelaciona de forma sugestiva o académico com o emocional. Estamos perante um livro que tem muito de retrato geracional daqueles que, falando a partir de um lugar denso, o campo do detido-desaparecido, renunciam ao heroísmo para dar conta da possibilidade de viver nesse espaço e construir uma identidade. O Gabriel Gatti sociólogo e investigador e o Gatti familiar de desaparecido (filho de, irmão de...), depositário 
das memórias duma geração, estão sempre em tensão e obrigam-no com frequência a passar de entrevistador a entrevistado. Talvez seja precisamente dessa tensão que surge uma narrativa e uma forma de fazer sociologia ("uma sociologia a partir do estômago") que oferece ao leitor a oportunidade de seguir o percurso do autor no processo da sua investigação mediante numerosas notas do seu diário de campo que se encontram inseridas em caixas destacadas, muitas das quais denotando essa tensão omnipresente entre o académico e o emocional. Trata-se de uma narrativa que promove a polifonia através de quatro textos breves de diferentes autorias inseridos ao longo do livro, que dialogam com o autor apresentando outros pontos de vista a partir desse campo do detido-desaparecido e fora dele.

Os dois primeiros capítulos do livro constituem o seu esqueleto teórico. O primeiro é dedicado ao conceito de catástrofe enquanto factor analítico dos efeitos do desaparecimento forçado; o segundo descreve a devastação do binómio identidade/linguagem promovida pelo Estado moderno no contexto do Cone Sul latino-americano. Partindo do trabalho de diversos autores, como Giorgio Agamben e Zygmunt Bauman, que reflectem sobre as relações entre Estado, política e ordem social na lógica moderna, e mais concretamente sobre as formas de entender o Holocausto nessa lógica, assim como da análise de Norbert Elias sobre o processo de construção (civilização) do indivíduo moderno, Gatti estabelece que para os contextos argentino e uruguaio, o detido-desaparecido se encontra ligado à forma peculiar como foi historicamente construída a identidade nesses territórios: através da aplicação obsessiva do projecto moderno que tem no Estado jardineiro o seu executor principal. À luz deste processo histórico, Gatti explora a ideia de que o indígena poderia ser considerado como o primeiro "desaparecido": o Estado passou da acção sobre "o Índio e o deserto" à actuação sobre "o subversivo e a subversão". O autor adverte que o projecto dos jardineiros da biopolítica desenvolvido na América Latina foi levado à "perfeição" no Cone Sul pela via da conquista e destruição das cidades e populações indígenas, enquanto noutros contextos, como por exemplo na região andina, a sua história contemporânea não pode ser contada sem a "tradição pré-colonial”. Neste ponto seria talvez mais apropriado falarmos de permanência das culturas "originárias" nas formas contemporâneas e, portanto, da coexistência de diversas formas de pensar (ou não) o indivíduo.

Seguindo estas premissas, o autor estabelece o que denomina como o paradoxo do detido-desaparecido (que, no entanto, é enunciado apenas no final do quinto capítulo), segundo o qual o detido-desaparecido faz parte de um tipo de gestão de populações própria da ordem civilizadora moderna, sendo o desaparecimento forçado aplicado aos produtos mais acabados desta ordem: o indivíduo moderno/racional foi despedaçado - o desaparecido "deixa" um nome sem um corpo - sendo portanto aniquilado. Encontramo-nos perante uma proposta teórica vigorosa, que convida a uma análise comparada com outros contextos latino-americanos. Quais as consequências deste quadro na análise dos processos de conflito armado ocorridos nas últimas décadas em países como o Peru e a Guatemala, onde as comunidades rurais e as populações indígenas foram as mais afectadas? Mesmo correndo o risco de generalizar, podemos notar que a política de arrasamento aplicada pelas Forças Armadas peruana e guatemalteca teve como objectivo o aniquilamento do índio subversivo, que nos casos argentino e uruguaio não corresponde a uma, mas a duas 
figuras que "pertencem" a momentos históricos distintos. Assim, poderíamos considerar que, na política do Estado "jardineiro" peruano e guatemalteco, como no Cone Sul, o desaparecimento é, em grande medida, uma continuação da política de arrasamento de raiz colonial e republicana, mas que nos primeiros casos o indivíduo racional moderno, o cidadão, não substituiu o índio. Para além das diferenças nos processos de violência mencionados em relação aos acontecimentos no Cone Sul, consideramos que, mais do que na particularidade do terror de Estado na Argentina e Uruguai, devido ao modo peculiar como se constituiu a identidade nesses contextos - sendo que Gatti sublinha este último aspecto de uma forma talvez excessiva -, é nos efeitos e modos diferentes de viver (e narrar) esse espaço do detido-desaparecido que se encontram os elementos mais frutíferos para a análise comparada entre contextos latino-americanos. Retornarei a esta questão mais adiante.

Os quatro capítulos seguintes do livro são consagrados aos efeitos produzidos pela catástrofe do desaparecimento forçado na identidade e na linguagem. Os capítulos terceiro e quarto dedicam-se à análise das narrativas do sentido, aquelas que tratam de reparar e reequilibrar a catástrofe. A postura do autor em relação a estas narrativas é arriscada, inclusive irreverente, e para muitos leitores pode mesmo resultar injusta. Vejamos: as tentativas de dar sentido à catástrofe, pergunta-se Gatti, não serão formas de desvirtuá-la? Isto é, não estarão a dotar o desaparecido de uma identidade, de uma realidade que não tem, sendo que é precisamente essa carência (o sem sentido) a característica principal desse espaço e dessa figura? Partindo desta perspectiva, o capítulo terceiro centra-se na institucionalização da memória e, portanto, do próprio campo do detido-desaparecido através da burocracia, da profissionalização e pa- trimonialização encarnada nos arquivos e registos onde os cidadãos tentam recuperar a identidade do desaparecido e a sua própria, restaurando o que foi destroçado, e superando o trauma.

Contudo, é nas narrativas surgidas em torno das famílias de crianças desaparecidas/apropriadas - algumas das quais são $j a ́$ adultos recuperados - que o autor percebe os efeitos mais conservadores dos "militantes do sentido", na sua ênfase a um retorno a visões essencialistas e deterministas da identidade (i.e. a equação Identidade $=A D N$ ). Obviamente que, partindo de determinadas perspectivas da sociologia e da antropologia da identidade, como Elixabete Imaz reflecte no texto inserido neste capítulo, não é fácil aceitar a consideração do vínculo que a genética consegue demonstrar, e que foi destruído pela apropriação de crianças, como a essência duma identidade que deve ser restaurada. Para os sociólogos, é difícil pensar a partir duma identidade originária que foi suplantada e deve ser recuperada. No entanto, o que parece perturbar mais o autor não é tanto o essencialismo destas narrativas da identidade, mas a sua obsessão em reequilibrar aquilo que foi abruptamente desestabilizado porque, de certo modo, correspondem a formas de obliteração da catástrofe produzida pelo desaparecimento.

O que Gatti demonstra é a forma como, perante um desaparecimento forçado, o imaginário moderno da identidade (individual e colectiva), com os seus contornos fixos, duráveis, depurados, é desdobrado e reforçado. Podemos voltar a discutir as diferenças e semelhanças com outros contextos. Relembro aqui que muitos dos cientistas sociais que trabalharam no processo da Comissão da Verdade e da Reconciliação peruana recorreram frequentemente ao exemplo argentino para denunciar o facto de as mães peruanas que reclamavam ao Estado o desaparecimento dos seus 
filhos serem mulheres camponesas, analfabetas, com um conhecimento rudimentar ou inexistente do castelhano - em oposição às mães da Praça de Maio, brancas, urbanas, letradas - como um aspecto fundamental da negação pelo Estado, pela justiça e por parte da sociedade peruana destas práticas sistemáticas de violência. Certamente, por excesso ou por defeito, quando se trata de reivindicar ao Estado a reparação do que foi perpetrado a partir do seu interior, o imaginário e os dispositivos modernos desdobram-se. Apesar de, em contextos como o peruano, podermos considerar que o terror de Estado não foi exercido - tal como é enunciado no paradoxo do detido-desaparecido - da forma mais brutal sobre os seus produtos "mais acabados”, a sua lógica de acção foi similar e muitas das narrativas possíveis aí surgidas são idênticas às que acontecem no Cone Sul, porque se encontram centradas no binómio Estado/cidadão. Contudo, existem duas distinções fundamentais. Por um lado, no Cone Sul, o propósito dessas narrativas do sentido é restituir ao indivíduo a sua condição cidadã, enquanto noutros contextos se trata de tentativas de "produção" de cidadania em territórios e para populações que só de forma precária foram considerados como tal. Por outro lado, a institucionalização das narrativas do sentido no Cone Sul, mais concretamente na Argentina, foi possível porque o Estado assumiu como próprio o discurso dos familiares dos desaparecidos, "depurado" pela doutrina dos Direitos Humanos. Esta espécie de consenso não tem acontecido noutros contextos latino-americanos.

Os últimos dois capítulos do livro são dedicados às narrativas que, ao contrário das anteriores, não buscam o equilíbrio. São narrativas que constroem identidade partindo do sem sentido que se produz ao habitar a catástrofe do campo do detido-desaparecido. Gabriel Gatti está mais confortável nestas narrativas - que são a sua própria - porque se afastam da épica política e porque, partindo da "experiência normalizada" que faz do vazio um lugar, provocam a reflexividade em torno da impossibilidade de reequilibrar a catástrofe. Estas narrativas facilitam a auto-paródia, a piada e, simultaneamente, uma representação, quiçá mais crua, da catástrofe. Destacamos a análise que Gatti faz das obras e discursos de vários artistas, como o fotógrafo Gustavo Germano e a cineasta Albertina Carri. As fotografias de Germano retratam a ausência, mas não tentam preenchê-la nem imaginar como que seria o presente sem essas ausências. Contrastando com os discursos que tentam restabelecer a temporalidade interrompida pelo desaparecimento e recompor a cadeia da linhagem, estas narrativas não procuram esse reequilíbrio. Por outro lado, no filme Los Rubios, Albertina Carri mostra a reconstrução da história da sua família através dos testemunhos daqueles que conheceram os seus pais e os companheiros de militância. No entanto, ela não pretendia retratar essa história, mas a sua própria, que não é mais do que uma "convivência com a ausência", como a de tantos outros da sua geração, reflectindo assim também sobre a distância e a incompreensão que esta postura teve para muitos.

Para aqueles que estejam familiarizados com o trabalho teórico de Gatti sobre a identidade colectiva, será fácil perceber neste contexto as ligações com a análise do que tem denominado como "identidades débeis" (Identidades Débiles. Una propuesta teórica aplicada al estudio de la identidad en el País Vasco, Madrid: CIS, 2007). Estarão estas narrativas do sem sentido a ser construídas a partir de identidades débeis? De acordo com o que Gatti nos aponta assim é: são narrativas onde não se pretende equilibrar as três componentes constitutivas das identidades (fortes) mo- 
dernas - o nome (próprio e único), o território (fechado e claro) e a história (com uma origem unívoca) -, mas antes viver e construir a identidade na precariedade dos vínculos entre estes três aspectos. Contudo, será que dependem da institucionalização do campo do detido-desaparecido promovido pelas narrativas do sentido, mais conservadoras, mais "modernas", mas necessárias? Percebe-se na despedida irritada com a qual finaliza o livro que Gatti responde afirmativamente a esta última questão. Nessas derradeiras páginas Gatti dá conta do seu desconforto com o que considera "o sigilo uruguaio", isto é, com o facto da realidade do detido-desaparecido não estar ainda assumida nesse país e, em consequência, não serem assumidas as dimensões da acção do Estado uruguaio. Por outro lado, o "excesso argentino", apesar dos seus efeitos conservadores, patrimonializantes, estatocêntricos - ou mais precisamente devido a eles -, é um tom justo para o autor.
Estamos perante um livro teórica e analiticamente denso, estimulante, importante para aqueles que pretendam compreender a partir doutro ângulo o terror de Estado, para além das questões da memória e da chamada justiça transicional. Trata-se de um livro ousado relativamente a certas narrativas e abordagens sobre esta temática imersas num discurso previsível demais, que o autor considera menos capazes para dar conta doutras experiências. Porque Gabriel Gatti nunca abandona a perspectiva a partir da qual escreve, essa "sociologia a partir do estômago" é uma forma de fazer sociologia que converte este livro numa obra emotiva, que se alimenta da necessidade que muitos dos que habitam no espaço de detido-desaparecido sentiram - como descreve Daniel Gatti no seu texto inserido na introdução - de rebelar-se contra o estado transitivo de vítima, e contra os emblemas e militâncias que "deviam" carregar.

Silvia Rodríguez Maeso

\section{Shapin, Steven (2008), The Scientific Life: A Moral History of a Late Modern Vocation. Chicago e Londres: The University of Chicago Press, 468 pp.}

O que é a vida científica, que tipo de pessoa é o cientista e que virtudes e capacidades mobiliza para aumentar o seu poder financeiro e de influência, são algumas perguntas a que Steven Shapin, Professor de História da Ciência na Universidade de Harvard, tenta responder no seu mais recente livro, intitulado The Scientific Life: A Moral History of a Late Modern Vocation. Os cientistas são especialistas respeitados, legitimados, a quem é confiada a tarefa de analisar e a compreender os fenómenos da realidade natural e social. A visão actual é que os cientistas não são nem melhores nem piores que ninguém e que o aumento das competências técnicas não é obrigatoriamente acompanhado por aumento se- melhante nas virtudes pessoais. The Scientific Life pode ser sintetizado com recurso ao comentário de David Edgerton, autor de The Shock of the Old, apresentado na capa do livro: os mundos da tecnociência actual, onde assumem nova importância o capital de risco, a investigação aplicada ou as relações universidade-empresa, não são as antíteses sem alma, excessivas em rotinas e em burocracias, do ideal científico académico - eles contêm em si facetas adequadas a um contexto de incerteza em que a inovação é essencial. Shapin acaba por afastar-se, deste modo, quer da visão romântica da ciência (que defende as virtudes "naturais" e o carácter transcendente do cientista), quer da desilusão na ciência 
(quando esta é vista como um meio de apropriação de riqueza e de benefícios próprios, em que o cientista é apenas mais um trabalhador como todos os outros, com os seus interesses egoístas), criando um meio-termo em que os valores continuam tão (ou mais) presentes agora do que alguma vez estiveram.

O livro organiza-se em torno de oito capítulos que tentam percorrer de forma cronológica os mundos da ciência e da tecnologia desde a Inglaterra do século XVII aos EUA do século XXI.

O primeiro capítulo, "Knowledge and Virtue: The Way We Live Now", introduz o tema e apresenta as diferentes componentes do livro. Shapin explicita os seus objectivos: o primeiro, mostrar como e porquê as pessoas e as suas virtudes interessam na produção e na autoridade dos elementos do conhecimento técnico na modernidade tardia; o segundo, discutir por que razão hoje em dia esta é uma referência estranha e quase perversa. Actualmente, fala-se da desmoralização dos especialistas, uma dimensão indesmentível desta modernidade tardia, que, como insiste Shapin, coexiste com sentimentos contrários em que a virtude e moral têm lugar. O livro é apresentado não como pertencendo à Sociologia do Conhecimento Científico, mas como mais próximo de uma História Cultural ou de uma análise alargada das formas de comportamento individual e da sua relação com as instituições. Shapin apresenta os seus objectos de interesse como todos aqueles que estão amarrados à tecnociência, ligando este conceito ao trabalho de Bruno Latour, que resulta da noção da incapacidade de distinguir o que pertence à ciência, à sociedade, à economia ou à política. $\mathrm{O}$ autor utiliza este referencial para seguir não só os actores e os seus comportamentos, mas as próprias materialidades resultantes desta visão mais complexa.
Os segundo e terceiro capítulos tratam de iluminar a transformação cultural e social da ciência enquanto vocação para a ciência como emprego, em muitos casos uma transição incompleta. O capítulo 2, "From Calling to Job: Nature, Truth, Method, and Vocation. From the Seventeenth to the Nineteenth Centuries", traça o percurso desde as concepções de filósofo da natureza, enquanto chamamento de aproximação a Deus (o conhecedor ligava-se à própria característica do objecto do conhecimento, fruto de criação divina), até ao período de recusa de qualquer superioridade moral ao cientista. $\mathrm{Na}$ análise da própria ciência, a ideia do valor da "genialidade" e das capacidades individuais foi vista como um obstáculo à afirmação da Sociologia do Conhecimento, que Robert Merton queria fortalecer, em que deveriam ter papel central as normas e ethos internalizados pelos indivíduos mas com origem na comunidade. O carácter do próprio cientista estava envolvido com as concepções do que era o conhecimento científico e do que os cientistas faziam para garantir o conhecimento e a manutenção das estruturas que asseguravam poder e riqueza. O capítulo 3, "The Moral Equivalence of the Scientist: A History of the Very Idea", segue a história desde o início do século XX até à Segunda Guerra Mundial. Esta guerra foi, aliás, um forte catalisador para a secularização do poder da ciência. $\mathrm{O}$ aspecto central do debate é a equivalência moral do cientista, o facto de os cientistas serem humanos. Como mencionava Einstein em 1921 (citado na p. 49), seleccionar uns quantos indivíduos para admiração sem limites, atribuindo-lhes poderes sobre-humanos de carácter e intelecto, parecia injusto e até de mau gosto, em particular com a emergência da Big Science e da controvérsia em torno da falta de integridade e de limites que a ciência mostrava (por exemplo, com o projecto Manhattan e o 
lançamento das bombas de Hiroshima e Nagasaki). Este novo contexto não deixou de ser contestado por muitos e visto como sinal de que algo ia mal com a ciência moderna, amarrada na altura a um complexo industrial e militar. A integração da ciência nas estruturas civis, que projectaram o poder e favoreceram a acumulação de riqueza, teve consequências na compreensão social do papel do cientista e na própria visão do conhecimento científico. O papel da ciência deixou de ser visto como possuidor de virtudes especiais, e os cientistas seriam apenas mais um dos grupos de interesse. Na visão de alguns, a universidade permanecia o refúgio e casa "natural" da ciência como busca de moralidade e conhecimento, livres da autoridade, da burocratização e da organização dos ambientes industriais e militares.

O capítulo 4, "Who is the Industrial Scientist: The View From the Tower", mostra esta nova ciência, apresentando o cientista industrial a partir da perspectiva da academia e notando como os sociólogos alertaram para as violações dos valores essenciais da ciência que ocorreram com esta industrialização. As ideias mertonianas de universalismo, desinteresse e anti-autoritarismo estavam em causa, ameaçando a objectividade do conhecimento científico, pressionada pelos novos problemas do laboratório industrial, focado em problemas de rendibilidade e segurança (principalmente no contexto da Guerra Fria). Estes cientistas a trabalhar na indústria eram substancialmente mais bem pagos que os que permaneciam no ambiente universitário, e até o grupo mais mal pago na indústria, o dos biólogos, tinha uma situação favorável face aos mais bem pagos na universidade, os engenheiros (106). Para trabalhadores com menos de trinta anos, a média salarial não era muito diferente, mas existia um leque mais alargado de oportunidades. Para os cientistas que permane- ceram no ambiente universitário, pouco mudou em relação ao contexto institucional, mas para aqueles que derivaram para a indústria não. Houve uma facção que ficou bastante traumatizada com o confronto com alguns dos valores em que se baseava a actividade industrial: o segredo, a hierarquia, o curto prazo, o dinheiro. Esta situação gerou tensão com uma ciência que se pensava construída por homens normais mas que, apesar disso, no mundo universitário, estavam ligados às virtudes da vida científica. $\mathrm{Na}$ indústria tudo era diferente: apenas se justificava a continuidade de um trabalho de investigação caso se perspectivassem resultados práticos.

O capítulo 5, "Who is the Industrial Scientist: The View From the Managers", discute a criação do conhecimento em contexto industrial na perspectiva dos gestores, introduzindo a noção de incerteza normativa. Esta incerteza está ligada, em alguma medida, a todas as iniciativas de investigação, e era altamente apreciada pelos que estavam envolvidos na ciência industrial. A maior parte da investigação falha para alcançar os seus objectivos. Deste modo, apostar em actividades de investigação na indústria justifica-se pelo grande valor dos poucos sucessos. Para gerir esta incerteza, nos resultados e nos próprios processos de investigação, a ciência industrial sentiu necessidade de contabilizar a investigação, ligando, por exemplo, o ritmo de produção aos resultados obtidos. Assim surgiu um alargado conjunto de documentos para reportar esta visão mais contabilística de avaliação da investigação (ilustrados pelo autor com os cartões dos laboratórios da Kodak para problemas encontrados nos processos de investigação). A ideia de que a academia oferecia liberdade e autonomia absoluta foi-se tornando um contra-senso devido à necessidade de obter fundos, à disponibilidade das publicações científicas para aceitarem apenas determinados temas 
e às restrições impostas pela própria disciplina e pelos departamentos das universidades. Apesar do enfoque em resultados práticos e em linhas de investigação que poderiam ser consideradas fechadas, as empresas começaram a incentivar os seus investigadores a estabelecerem laços com as universidades e a participarem em iniciativas comuns.

O capítulo 6, "The Scientist and the Civic Virtues: The Moral Life of Organized Science", aborda um dos aspectos mais discutidos, alvo de críticas internas e externas, na Big Science, o trabalho em equipa (teamwork). A equipa era entendida pelos seus críticos de acordo com uma noção militarista de comando, hierarquia e controlo que impedia a originalidade e a criatividade do cientista enquanto indivíduo, mas na visão industrial era uma forma mais adequada de se alcançarem as metas desejadas, porque ficava menos dependente de um único indivíduo (que detinha o conhecimento, podendo comprometer todos os resultados da investigação se deixasse a empresa). A organização da ciência industrial implicou uma grande atenção ao planeamento da investigação. Shapin mostra como o cientista era um organization man, ligado aos seus contextos de grupo e enquadramento institucional. Nesta visão, a virtude não é expurgada da tecnociência mas antes reconfigurada. É interessante referir a ilustração que Shapin faz da relevância das virtudes pessoais na indústria recorrendo a uma outra materialidade, uma carta de recomendação para contratação de investigadores (186-187), em que virtudes pessoais como a honestidade, a capacidade de trabalhar em grupo, o contexto familiar, a confiabilidade, a fisionomia, mas também os receios da Guerra Fria (a lealdade aos EUA), são itens claramente listados e que deveriam ser alvo de avaliação da gestão. Emergiu a figura do director científico, indivíduo que corporizava os objectivos da empresa, do departamento ou do grupo, e que evidenciava a importância que as virtudes pessoais afinal continuavam a ter na autoridade moral na investigação científica e na criação das relações sociais na ciência.

O capítulo 7, "The Scientific Entrepreneur: Money, Motives and the Place of Virtue", aborda a forma como, no decorrer do século XX, o mundo da ciência passou a associar-se a um modo de vida mais confortável, o que se traduziu num interesse crescente de muitos que passaram a ver na ciência uma possibilidade atraente de emprego. Os cientistas passaram a ser associados a pessoas que querem ganhar dinheiro mas que também se querem divertir ("Fun and funds are not the same thing but they are related" [217]) e que se preocupavam com coisas mundanas como a fama ou o sexo. James D. Watson (estrutura do DNA), Richard Feynman (electrodinâmica quântica), Craig Venter (genoma humano) ou Kary Mullis (polymerase chain reaction - PCR) são exemplos de empreendedores-cientistas-vedetas que, para além dos seus contributos científicos, deram face a este novo tipo de investigador ligado ao hedonismo, a campanhas de publicidade ou a actividades de lazer e entretenimento (como o surf ou bonecos para crianças). A ciência enquanto vocação continuava a existir, mas, a partir dos meados dos anos setenta, passou a partilhar o seu espaço com esta nova tendência do cientista-empreendedor-vedeta. Para algumas áreas específicas, a possibilidade de um indivíduo ascender a grande riqueza através da ciência passou a ser uma realidade.

As diferenças entre a academia e a indústria ainda continuam a ser evidentes para muitos. Shapin refere vários investigadores que identificam estas diferenças: os investigadores industriais têm de se comprometer com as agendas de investigação da em- 
presa, têm de saber lidar com pessoas diferentes, perceber que existem várias hierarquias, equipas que se devem respeitar e que o ambiente é mais ditatorial. Pessoas que não respeitem estas lógicas não se dão bem na indústria. Mas, como o autor nota, esta visão refere-se essencialmente ao organization researcher dos anos sessenta e não tanto aos novos modelos assentes em start-ups de base de conhecimento. A actualidade da tecnociência faz-se com uma grande heterogeneidade moral, não há espaço para pensar que só existe um local, a universidade, onde se vive a "boa vida científica" (242). Os motivos do cientista-empreendedor para seguir esta via são ilustrativos de que a "boa vida" também acontece na empresa. Em primeiro lugar, é necessária vontade de fazer dinheiro (e não ver o lucro como um pecado). $\mathrm{O}$ ambiente empresarial é ideal para o pensamento livre e para gerar conhecimento científico que tenha lugar no mercado e que possa ajudar os outros. Não resulta afinal daqui nenhuma incompatibilidade dinheiro-ciência, mas até alguma complementaridade. O cientista-empreendedor pretende evoluir rapidamente, ter acesso à decisão e a níveis remuneratórios mais interessantes para o que considera serem as suas capacidades, algo que é inviabilizado pela lógica da academia, onde o tempo e a hierarquia são aspectos centrais na valorização do indivíduo. As entidades financiadoras da investigação, com o seu conservadorismo, são também limitadoras de propostas menos em linha com os objectivos dos mainstreams disciplinares. A competição excessiva pelos apoios e a exigente rotina de "publish or perish" são outras das desvantagens da universidade face à realidade empresarial, onde existe maior liberdade para focar as investigações no que realmente interessa na óptica da empresa. A obrigatoriedade e peso excessivo da carga lectiva também são aspectos que es- tes investigadores querem evitar ao irem para a indústria. O carisma dos empreendedores é um aspecto central do seu sucesso, o que recupera a importância das características pessoais.

O capítulo 8, "Visions of the Future: Uncertainty and Virtue in The World of High-Tech and Venture Capital", apresenta os futuros da tecnociência ligando o capital de risco às decisões de investimento em empresas de base científica e procurando perceber o processo de escolha das tecnologias, mercados e pessoas que poderão com mais probabilidade gerar retornos financeiros. A grande incerteza carece de decisões e juízos que tomam formas pessoais: as decisões sobre em que empresa investir tornam-se dependentes da valorização que se faz das pessoas- chave a que está associado determinado projecto. $\mathrm{O}$ autor apresenta exemplos de como actualmente se transformam as ideias com base em ciência em potenciais negócios. Plataformas como as asseguradas pelos centros de transferência de tecnologia das universidades são elementos essenciais para apoiar o lançamento de ideias com potencial mas ainda em processo de amadurecimento. Essas plataformas proporcionam a proximidade entre empreendedores, investidores, parceiros comerciais e técnicos que podem interessar-se pelo projecto, promovendo o contacto com saberes diferenciados, ligando o conhecimento ao seu potencial de mercado e partilhando aspirações e virtudes prezadas. Apesar de os investidores de risco não apreciarem a falta de visão para o negócio ou as limitadas capacidades de gestão de alguns investigadores, fica bem patente a sua admiração por aqueles que investem na compatibilização destas noções com o conhecimento técnico da sua área. Quer os venture capitalists quer estes novos cientistas consideram-se as elites que fazem avançar o mundo (300). 
No epílogo, “The Way We Live Now", é ilustrado como o mundo da tecnociência da modernidade tardia é complexo e composto por actores de diferentes esferas: cientistas, engenheiros, gestores de empresas importantes, business angels, capital de risco, agentes de propriedade industrial, gestores de transferência de tecnologia, responsáveis das universidades e dos centros de investigação, pessoas que se habituaram a transformar o conhecimento em artefactos, riqueza e poder (306). Nestes grupos, o networking assume importância central como processo de ligação social. O sucesso está muito condicionado pelas redes sociais nas quais se participa e naquelas a que se consegue obter acesso. Os actores não funcionam em rede total, mas dividem-se em várias sub-redes de afinidades e familiaridades pessoais. Esta é uma realidade que (com as devidas especificidades) é cada vez mais presente na situação científica portuguesa, onde começam a emergir este tipo de redes que tentam ligar a universidade e a empresa, tornando mais aceitável a ciência que se relaciona com a indústria e com o mercado. Um exemplo português, com paralelismos nos encontros descritos por Shapin, é a experiência das plataformas regionais do Programa FINICIA, uma iniciativa desenvolvida pelo IAPMEI (Instituto de Apoio às Pequenas e Médias Empresas e à Inovação) com o objectivo de facilitar o acesso ao financiamento a ideias empresariais de base de conhecimento. O objectivo explícito da iniciativa é garantir financiamento para a criação de start-ups inovadoras, mas muito mais tem sido alcançado. Estas plataformas, ao incluírem actores provenientes de todos os espectros da tecnociência, partilharam informação, ganharam confiança, densificando as relações existentes entre diferentes esferas institucionais.

Steven Shapin argumenta que não há razão para se rejeitar o ideal da investiga- ção desinteressada com base nos arranjos institucionais actuais e para se achar que existe diferença substancial entre a "boa vida científica" na academia e na indústria. Ameaças de interferência política, de imperativos de comercialização, excessos de profissionalização excessiva dos cientistas e de inflexibilidade das ortodoxias das disciplinas sempre existiram na ciência - e vão persistir. A evolução que a ciência sofreu foi muito intensa, mas não é necessário pensar que as virtudes do ideal de ciência académica não estão também presentes noutras vertentes da ciência na modernidade tardia. A diversidade de ambientes institucionais nos quais se concretiza a investigação actual e futura faz emergir a importância da vocação e das virtudes pessoais. Citando Shapin (18), "judgments of business opportunities and technologies proceed importantly through judgments of familiar people and their virtues". Afinal as pessoas continuam a contar, as suas virtudes contam. E a razão porque contam é que, devido à radicalidade da incerteza na modernidade tardia, é importante ter aspectos duráveis nos quais se possa confiar (303). Esta familiaridade é conseguida através da redescoberta das virtudes, que não estão afinal perdidas, pertencendo igualmente, ou especialmente, como destaca Shapin, ao mundo de fazer os mundos que hão-de vir.

Uma das discussões mal resolvidas com a apresentação de Shapin acaba por ser qual o papel da moral na ciência. Que o mundo da tecnociência não é ausente de valores é incontestável, mas serão os valores hoje emergentes e centrais na vida do cientista adequados a uma ciência moral? Um paradigma centrado na importância da empresa individual, do carisma e do individualismo, no imediatismo, no lucro, no resultado evidente, onde os limites éticos ficam muitas vezes por discutir, origina 
182 | Recensões

uma ciência moralmente ambígua. Em ponto. É o caminho para onde ela parece épocas de crise na economia, na sociedade dirigir-se com cada vez mais vigor. O dee nos valores, fica muito por dizer acerca bate fica em aberto...

de ser este o caminho certo para a ciência.

Mas Shapin não tem contestação num Hugo Pinto 